MATEC Web of Conferences 23,01023 (2015)

DOI: $10.1051 /$ matecconf/ 20152301023

(C) Owned by the authors, published by EDP Sciences, 2015

\title{
Optimization of the Characteristics of High-Energy Materials
}

\author{
Viktoriya Kuznetsova ${ }^{1}$, Lilia Savelieva ${ }^{2}$ \\ ${ }^{1}$ Tomsk State University, Tomsk, Russia \\ ${ }^{2}$ Tomsk State University, Research Institute of Applied Mathematics and Mechanics, Tomsk, Russia
}

\begin{abstract}
In work explored effect of mixed metallic fuel on the thermodynamic and ballistic characteristics of High-Energy Materials (HEMs). Efficiency of mixed metallic fuel estimated in relation to the characteristics of HEMs, containing conventional metallic fuel - aluminum. The main criteria of comparison are the specific impulse and the composition of the combustion products HEMs.
\end{abstract}

Keywords: perchlorate high-energy materials, mixed metallic fuel, specific impulse, condensed combustion products, hydrogen chloride.

\section{INTRODUCTION}

Modern HEMs compositions are based on three components: the inert fuel-binder -butadiene rubber SKDM-80; the oxidizer ammonium perchlorate (AP); metallic fuel - individual metals and mechanical mixtures on their basis [1].

The main energy component of HEMs is the metallic fuel. Metallic fuel determines the energy characteristics of fuels (specific impulse, the temperature in the combustion chamber and at the nozzle outlet) and influences the composition of the gaseous combustion products and the content of condensed substances. Along with energy characteristics the metals and metal-containing substances increases the density of the fuel, which also increases the efficiency of its application in rocket engines based on solid fuel [2].

The main requirements to modern HEMs:

1) specific impulse of not less than $250 \mathrm{c}$;

2) reduction of the hydrogen chloride $(\mathrm{HCl})$ content in the gaseous combustion products of HEMs in comparison with the systems containing the initial aluminum;

3) minimization of the content of condensed substances in the combustion products of HEMs;

4) optimization of the ratio of fuel mass to the mass of the engine, i.e. the use of heavy metallic fuel.

The efficiency of fuel is dependent on the heat of formation of products of complete oxidation of metallic fuel. Table 1 shows the characteristics of metallic fuels and their oxides, taken from [3].

Table 1. Characteristics of metallic fuels and metallic oxides

\begin{tabular}{|c|c|c|c|c|c|}
\hline & metallic fuel & $\rho_{\mathrm{Me}}, \mathrm{\kappa} / \mathrm{M}^{3}$ & $\mathrm{Me}_{\mathrm{n}} \mathrm{O}_{\mathrm{m}}$ & $\rho_{\text {MenOm }}, \mathrm{kg} / \mathrm{m}^{3}$ & $Q, \mathrm{~kJ} \mathrm{~kg}$ \\
\hline 1 & $\mathrm{Al}$ & 2.698 & $\mathrm{Al}_{2} \mathrm{O}_{3}$ & $3.50-4.10$ & 16.137 \\
\hline 2 & $\mathrm{Mg}$ & 1.741 & $\mathrm{MgO}$ & $3.20-3.70$ & 15.172 \\
\hline 3 & $\mathrm{~B}$ & 2.330 & $\mathrm{~B}_{2} \mathrm{O}_{3}$ & 1.84 & 20.985 \\
\hline 4 & $\mathrm{Si}$ & 2.326 & $\mathrm{SiO}_{2}$ & $2.20-2.65$ & 21.631 \\
\hline 5 & $\mathrm{~W}$ & 19.270 & $\mathrm{WO}_{3}$ & 7.00 & 4.568 \\
\hline 6 & $\mathrm{Ti}$ & 4.505 & $\mathrm{TiO}_{2}$ & $3.84-4.26$ & 11.418 \\
\hline
\end{tabular}

On the basis of values of the densities of the metals and the heat of formation of metallic oxides for further study were selected the metallic fuels aluminum $(\mathrm{Al})$, magnesium $(\mathrm{Mg})$, boron $(\mathrm{B})$, silicon $(\mathrm{Si})$, titanium $(\mathrm{Ti})$ and mixtures based thereon.

\section{METHOD OF RESEARCH}

The energy and thermodynamic characteristics of HEMs was determined by the results of thermodynamic calculation by software package "Astra-4" [4]. The initial data for thermodynamic calculations are: the content of components in HEMs (wt.\%), the equivalent formulas of HEMs and the enthalpies of formation $\Delta H$. The calculations are carried out at a predetermined pressure in the combustion chamber $p_{\mathrm{K}}$ and at the nozzle outlet $p_{\mathrm{a}}$. The calculations were carried out at a pressure in the combustion chamber 4.0 MPa and at the nozzle outlet $0.1 \mathrm{MPa}$. 
We considered HEMs, containing 15 wt. \% metallic fuel with oxidizer excess coefficient $(\alpha)$ equal to 0.5 . Table 2 shows the compositions, the equivalent formulas and the enthalpies of formation of investigated HEMs.

Table 2. Composition, the equivalent formula and the enthalpy of formation of HEMs.

\begin{tabular}{|c|c|c|c|c|c|c|}
\hline \multirow{2}{*}{ № } & \multirow{2}{*}{ metallic fuel } & \multicolumn{3}{|c|}{ Content of components, $\%$} & \multirow{2}{*}{ Equivalent formula } & \multirow{2}{*}{$\Delta H, \mathrm{~kJ} / \mathrm{kg}$} \\
\hline & & metallic fuel & SKDM-80 & AP & & \\
\hline 1 & $\mathrm{Al}$ & 15 & 16 & 69 & $\mathrm{C}_{11.527} \mathrm{H}_{44.256} \mathrm{~S}_{0.023} \mathrm{O}_{23.589} \mathrm{Cl}_{5.897} \mathrm{Al}_{5.556} \mathrm{~N}_{5.897}$ & -1908.926 \\
\hline 2 & $\mathrm{Mg}$ & 15 & 17 & 68 & $\mathrm{C}_{12.247} \mathrm{H}_{45.207} \mathrm{~S}_{0.024} \mathrm{O}_{23.248} \mathrm{Cl}_{5.812} \mathrm{Mg}_{6.168} \mathrm{~N}_{5.812}$ & -1829.384 \\
\hline 3 & B & 15 & 11 & 74 & $\mathrm{C}_{7.925} \mathrm{H}_{39.508} \mathrm{~S}_{0.016} \mathrm{O}_{25.299} \mathrm{Cl}_{6.325} \mathrm{~B}_{13.863} \mathrm{~N}_{6.325}$ & -1980.239 \\
\hline 4 & $\mathrm{Si}$ & 15 & 17 & 68 & $\mathrm{C}_{12.247} \mathrm{H}_{45.207} \mathrm{~S}_{0.024} \mathrm{O}_{23.248} \mathrm{Cl}_{5.812} \mathrm{Si}_{5.340} \mathrm{~N}_{5.812}$ & -1829.384 \\
\hline 5 & $\mathrm{Ti}$ & 15 & 17 & 68 & $\mathrm{C}_{12.247} \mathrm{H}_{45.207} \mathrm{~S}_{0.024} \mathrm{O}_{23.248} \mathrm{Cl}_{5.812} \mathrm{Ti}_{3.132} \mathrm{~N}_{5.812}$ & -1829.384 \\
\hline 6 & $\mathrm{Al} / \mathrm{Mg}$ & $7.5 / 7.5$ & 16 & 69 & $\mathrm{C}_{11.527} \mathrm{H}_{44.256} \mathrm{~S}_{0.023} \mathrm{O}_{23.589} \mathrm{Cl}_{5.897} \mathrm{Al}_{2.778} \mathrm{Mg}_{3.084} \mathrm{~N}_{5.897}$ & -1908.926 \\
\hline 7 & $\mathrm{Al} / \mathrm{B}$ & $7.5 / 7.5$ & 13 & 72 & $\mathrm{C}_{9.366} \mathrm{H}_{41.407} \mathrm{~S}_{0.019} \mathrm{O}_{24.615} \mathrm{Cl}_{6.154} \mathrm{Al}_{2.778} \mathrm{~B}_{6.932} \mathrm{~N}_{6.154}$ & -1951.714 \\
\hline 8 & $\mathrm{Al} / \mathrm{Si}$ & $7.5 / 7.5$ & 16 & 69 & $\mathrm{C}_{11.527} \mathrm{H}_{44.256} \mathrm{~S}_{0.023} \mathrm{O}_{23.589} \mathrm{Cl}_{5.897} \mathrm{Al}_{2.778} \mathrm{Si}_{2.670} \mathrm{~N}_{5.897}$ & -1908.926 \\
\hline 9 & $\mathrm{Al} / \mathrm{Ti}$ & $7.5 / 7.5$ & 16 & 69 & $\mathrm{C}_{11.527} \mathrm{H}_{44.256} \mathrm{~S}_{0.023} \mathrm{O}_{23.589} \mathrm{Cl}_{5.897} \mathrm{Al}_{2.778} \mathrm{Ti}_{1.566} \mathrm{~N}_{5.897}$ & -1908.926 \\
\hline 10 & $\mathrm{Al} / \mathrm{Mg} / \mathrm{B}$ & $5 / 5 / 5$ & 14 & 71 & $\mathrm{C}_{10.000} \mathrm{H}_{44.273} \mathrm{O}_{24.273} \mathrm{Cl}_{6.068} \mathrm{Al}_{1.852} \mathrm{Mg}_{2.056} \mathrm{~B}_{4.621} \mathrm{~N}_{6.068}$ & -1937.452 \\
\hline 11 & $\mathrm{Al} / \mathrm{Mg} / \mathrm{Si}$ & $5 / 5 / 5$ & 16 & 69 & $\mathrm{C}_{11.429} \mathrm{H}_{46.446} \mathrm{O}_{23.589} \mathrm{Cl}_{5.897} \mathrm{Al}_{1.852} \mathrm{Mg}_{2.056} \mathrm{Si}_{1.780} \mathrm{~N}_{5.897}$ & -1908.926 \\
\hline 12 & $\mathrm{Al} / \mathrm{B} / \mathrm{Si}$ & $5 / 5 / 5$ & 14 & 71 & $\mathrm{C}_{10.000} \mathrm{H}_{44.273} \mathrm{O}_{24.273} \mathrm{Cl}_{6.068} \mathrm{Al}_{1.852} \mathrm{~B}_{4.621} \mathrm{Si}_{1.780} \mathrm{~N}_{6.068}$ & -1937.452 \\
\hline 13 & $\mathrm{Al} / \mathrm{Ti} / \mathrm{Mg}$ & $5 / 5 / 5$ & 16 & 69 & $\mathrm{C}_{11.429} \mathrm{H}_{46.446} \mathrm{O}_{23.589} \mathrm{Cl}_{5.897} \mathrm{Al}_{1.852} \mathrm{Ti}_{1.044} \mathrm{Mg}_{2.056} \mathrm{~N}_{5.897}$ & -1908.926 \\
\hline 14 & $\mathrm{Al} / \mathrm{Mg} / \mathrm{B}$ & $7 / 5 / 3$ & 15 & 70 & $\mathrm{C}_{10.714} \mathrm{H}_{45.361} \mathrm{O}_{23.932} \mathrm{Cl}_{5.983} \mathrm{Al}_{2.593} \mathrm{Mg}_{2.056} \mathrm{~B}_{2.773} \mathrm{~N}_{5.983}$ & -1923.189 \\
\hline 15 & $\mathrm{Al} / \mathrm{Mg} / \mathrm{B}$ & $3 / 5 / 7$ & 14 & 71 & $\mathrm{C}_{10.000} \mathrm{H}_{44.273} \mathrm{O}_{24.273} \mathrm{Cl}_{6.068} \mathrm{Al}_{1.111} \mathrm{Mg}_{2.056} \mathrm{~B}_{6.469} \mathrm{~N}_{6.068}$ & -1937.452 \\
\hline
\end{tabular}

In the analysis of calculated data focuses on the following characteristics: specific impulse $I_{\mathrm{sp}}$, the combustion temperature in the chamber $T_{\mathrm{eq}}$ and at the nozzle outlet $T_{\mathrm{ad}}$, the content of condensed combustion products and hydrogen chloride, the average molar mass of the combustion products.

\section{RESULTS AND DISCUSSION}

The efficiency of investigated HEMs was determined by the formula

$$
K=\frac{B_{M e}}{B_{A l}},
$$

where $B_{M e}$ - characteristic of HEMs, containing the investigated metallic fuel; $B_{A l}$ - characteristic of HEMs, containing 15 wt. $\%$ aluminum [5].

Table 3 shows the results of thermodynamic calculations of HEMs, containing individual metallic fuel. 
Table 3. Thermodynamic characteristics of HEMs, containing individual metallic fuel

\begin{tabular}{|l|c|c|c|c|c|c|c|c|c|c|}
\hline & metallic fuel & $T_{\text {eq }}, \mathrm{K}$ & $T_{\text {ad }}, \mathrm{K}$ & $I_{\text {sp }}, \mathrm{sec}$ & $K_{\text {Isp }}$ & $\begin{array}{c}\text { The average molar } \\
\text { mass, g/mol }\end{array}$ & \multicolumn{2}{|c|}{ Content, \% } & \multirow{2}{*}{$K_{\text {cond. phase }}$} & $K_{\mathrm{HCl}}$ \\
\cline { 8 - 10 } & $\mathrm{Al}$ & 3051 & 1733 & 268 & 1.00 & 18.215 & 28.3 & 21.5 & 1.00 & 1.00 \\
\hline 2 & $\mathrm{Mg}$ & 2725 & 1569 & 257 & 0.96 & 18.954 & 23.3 & 18.5 & 0.82 & 0.86 \\
\hline 3 & $\mathrm{~B}$ & 2590 & 1965 & 259 & 0.97 & 21.359 & 22.4 & 20.4 & 0.79 & 0.95 \\
\hline 4 & $\mathrm{Si}$ & 2944 & 1636 & 265 & 0.99 & 16.956 & 32.0 & 21.1 & 1.13 & 0.98 \\
\hline 5 & $\mathrm{Ti}$ & 2627 & 1357 & 244 & 0.91 & 18.954 & 23.7 & 21.2 & 0.84 & 0.99 \\
\hline
\end{tabular}

Introduction into the fuel 15 wt. \% aluminum provides specific impulse at the level 268 seconds and the temperature in the combustion chamber of the order of $3050 \mathrm{~K}$. However, in the combustion products of such fuels contains up to 28 wt. $\%$ condensed substances as alumina and up to $21 \mathrm{wt}$. \% hydrogen chloride vapor, which in real conditions leads to a reduction of the specific impulse and contradicts the requirements of ecological purity of combustion products of HEMs.

Magnesium and boron decreases the content of condensed substances on (18-21) \% relative to the initial aluminum, and the introduction of silicon increases the content of condensed phase by $13 \%$. Magnesium decreases the hydrogen chloride content in the combustion products by $14 \%$.

Table 4 shows the calculated thermodynamic characteristics of HEMs, containing mixed metallic fuel in the form of a mechanical mixture of different metals.

6-9 - fuel compositions, containing mixtures of double metals in the ratio $1 / 1$, and 10-13 - fuel compositions, containing mixtures of triple metals in the ratio $1 / 1 / 1$.

Table 4. Thermodynamic characteristics of HEMs, containing mixed metallic fuel

\begin{tabular}{|c|c|c|c|c|c|c|c|c|c|}
\hline & \multirow{2}{*}{ metallic fuel } & \multirow[b]{2}{*}{$T_{\text {eq }}, \mathrm{K}$} & \multirow[b]{2}{*}{$T_{\text {ad }}, \mathrm{K}$} & \multirow[b]{2}{*}{$I_{\mathrm{sp}}, \mathrm{sec}$} & \multirow{2}{*}{$\begin{array}{l}\text { The average molar } \\
\text { mass, } \mathrm{g} / \mathrm{mol}\end{array}$} & \multicolumn{2}{|l|}{ Content, $\%$} & \multirow[b]{2}{*}{$K_{\text {cond. phase }}$} & \multirow[b]{2}{*}{$K_{\mathrm{HCl}}$} \\
\hline & & & & & & condensed phase $(\mathrm{Z})$ & $\mathrm{HCl}$ & & \\
\hline 6 & $\mathrm{Al} / \mathrm{Mg}$ & 2896 & 1664 & 262 & 19.164 & 24.6 & 17.8 & 0.87 & 0.83 \\
\hline 7 & $\mathrm{Al} / \mathrm{B}$ & 2865 & 1933 & 266 & 19.961 & 24.6 & 21.5 & 0.87 & 1.00 \\
\hline 8 & $\mathrm{Al} / \mathrm{Si}$ & 3013 & 1710 & 267 & 17.756 & 30.2 & 21.5 & 1.07 & 1.00 \\
\hline 9 & $\mathrm{Al} / \mathrm{Ti}$ & 2878 & 1573 & 258 & 18.806 & 26.0 & 21.5 & 0.92 & 1.00 \\
\hline 10 & $\mathrm{Al} / \mathrm{Mg} / \mathrm{B}$ & 2855 & 1765 & 265 & 20.245 & 20.0 & 14.6 & 0.71 & 0.68 \\
\hline 11 & $\mathrm{Al} / \mathrm{Mg} / \mathrm{Si}$ & 2954 & 1665 & 267 & 17.792 & 28.5 & 21.2 & 1.01 & 0.99 \\
\hline 12 & $\mathrm{Al} / \mathrm{B} / \mathrm{Si}$ & 2877 & 1852 & 268 & 18.517 & 27.7 & 21.7 & 0.98 & 1.01 \\
\hline 13 & $\mathrm{Al} / \mathrm{Ti} / \mathrm{Mg}$ & 2850 & 1575 & 260 & 18.411 & 24.5 & 21.0 & 0.87 & 0.98 \\
\hline
\end{tabular}

The results show that the most interesting and effective is the triple mixture $\mathrm{Al} / \mathrm{Mg} / \mathrm{B}$, taken in the ratio $1 / 1 / 1$. Application of the triple mixture $\mathrm{Al} / \mathrm{Mg} / \mathrm{B}$ results in a marked decrease of condensed substances (29\%) and chlorine compounds in the combustion products $(32 \%)$ compared with the initial aluminum, which increases ecological purity of combustion products of HEMs. It should be noted that the change of the specific impulse of fuel is insignificantly.

In work performed the optimization of a mixture $\mathrm{Al} / \mathrm{Mg} / \mathrm{B}$ due to the change of the ratios of its components (table. 5).

Table 5. Thermodynamic characteristics of HEMs, containing the triple mixture Al/Mg/B

\begin{tabular}{|c|c|c|c|c|c|c|c|c|c|c|c|}
\hline & \multirow{2}{*}{\multicolumn{3}{|c|}{$\begin{array}{l}\text { Metallic fuel content } \\
\text { in HEMs, } \%\end{array}$}} & \multirow{3}{*}{$T_{\text {eq }}, \mathrm{K}$} & \multirow{3}{*}{$T_{\text {ad }}, \mathrm{K}$} & \multirow{3}{*}{$I_{\mathrm{sp}}, \mathrm{sec}$} & \multirow{3}{*}{$\begin{array}{l}\text { The average molar } \\
\text { mass, } \mathrm{g} / \mathrm{mol}\end{array}$} & \multicolumn{2}{|l|}{ Content, \% } & \multirow{3}{*}{$K_{\text {cond. phase }}$} & \multirow{3}{*}{$K_{\mathrm{HCl}}$} \\
\hline & & & & & & & & \multirow{2}{*}{ condensed phase $(\mathrm{Z})$} & \multirow{2}{*}{$\mathrm{HCl}$} & & \\
\hline & $\mathrm{Al}$ & $\mathrm{Mg}$ & $\mathrm{B}$ & & & & & & & & \\
\hline 10 & 5 & 5 & 5 & 2855 & 1765 & 265 & 20.245 & 20.0 & 14.6 & 0.71 & 0.68 \\
\hline 14 & 7 & 5 & 3 & 2881 & 1687 & 264 & 19.469 & 21.2 & 16.3 & 0.75 & 0.76 \\
\hline 15 & 3 & 5 & 7 & 2728 & 1808 & 264 & 20.074 & 20.9 & 11.7 & 0.74 & 0.54 \\
\hline
\end{tabular}

One of possible reason of influence of the triple mixture $\mathrm{Al} / \mathrm{Mg} / \mathrm{B}$ in the ratio $3 / 5 / 7$, i.e. with an excess of boron in relation to magnesium, may be the formation in the combustion wave of magnesium boride, which according to [6] is a combustion catalyst of HEMs. 


\section{CONCLUSIONS}

1. The use of mixed metallic fuel allows to optimize the characteristics of perchlorate HEMs in the predetermined direction. 2. The selection of the initial components of the mixed metallic fuel is advisable to carry out based on the analysis of their effect on the thermodynamic characteristics of HEMs on the predetermined direction.

3. It was established that the use of mixed metallic fuel $\mathrm{Al} / \mathrm{Mg} / \mathrm{B}$ in the ratio $3 / 5 / 7$ allows to reduce the hydrogen chloride content in 1.9 times and the content of condensed substances by 1.4 times.

Funding was provided by Tomsk State University Competitiveness Improvement Program (Project № 8.2.46.2015).

\section{REFERENCES}

1. Y.M. Paushkin, Liquid and solid chemical rocket propellants. (Moscow, Science, 1978)

2. S. Sarner, Chemistry of rocket fuels. (Moscow, Mir, 1969)

3. Quick Reference of chemist. (Moscow, State Publishing House of Chemical Literature, 1956)

4. B.G. Trusov, Modeling of chemical and phase equilibria at high temperatures "Astra-4" (Moscow, Bauman Moscow State Technical University Publishing House, 1991)

5. P.F. Pokhil, A.F. Belyaev, Y.V. Frolov, et al. Combustion of Powdery Metals in Active Media. (Moscow, Nauka, 1972)

6. B. Rozenband, Physics of combustion and explosion, 50, 34 (2014) 